\title{
Belt and Road Initiative (BRI) Blues: Powering BRI Research Back on Track to Avoid Choppy Seas
}

\author{
Jean-Marc F. Blanchard ${ }^{1,2}$
}

Accepted: 7 December 2020 /Published online: 5 January 2021

(C) The Author(s) 2021

\begin{abstract}
This piece examines and critiques the massive literature on China's ambitious Belt and Road Initiative (BRI). It details how research currently seems stuck on the road to nowhere. In addition, it identifies a number of the potholes that collective research endeavors are hitting such as that they are poorly synchronized. It also stresses that lines of analysis are proliferating rather than optimizing, with studies broadening in thematic coverage, rather than becoming deeper. It points out that BRI participants are regularly related to the role of a bit player in many analyses and research often is disconnected from other literatures. Among other things, this article recommends analysts focus on the Maritime Silk Road Initiative (MSRI) or Silk Road Economic Belt (SREB) in specific regions or countries. It also argues for a research core that focuses on the implementation issue (i.e., the issue of MSRI and SREB project implementation), project effects (i.e., the economic and political costs and benefits of projects), and the translation issue (i.e., the domestic and foreign policy effects of projects) and does work that goes beyond the usual suspects. On a related note, research need to identify, more precisely, participants and projects, undertake causal analysis, and take into account countervailing factors. Furthermore, studies need to make more extensive use of the Chinese foreign policy literature. Moreover, works examining subjects like soft power need to improve variable conceptualization and operationalization and deliver more nuanced analyses. Finally, studies, especially by area specialists, should take the area, not the China, perspective.
\end{abstract}

Keywords China $\cdot$ Belt and road initiative $\cdot$ Maritime silk road initiative $\cdot$ Silk road economic belt $\cdot$ Infrastructure $\cdot$ Political economy $\cdot$ Chinese foreign policy

Jean-Marc F. Blanchard

executive_director@mnccenter.org

1 School of Advanced International and Area Studies, East China Normal University (China), Shanghai, China

2 Mr. \& Mrs. S.H. Wong Center for the Study of Multinational Corporations (USA), Los Gatos, CA, USA 


\section{Introduction}

In a few years, it will be a decade since Chinese President Xi Jinping announced the Silk Road Economic Belt (SREB) and Maritime Silk Road Initiative (MSRI), collectively known as the Belt and Road Initiative (BRI). Most commentators see the People's Republic of China (PRC/China)'s breathtaking scheme, promulgated in 2013, as a gigantic connectivity venture which, through land and sea routes, will expand China's linkages westward to Europe. Following its birth, China's eyecatching initiative has drawn substantial and continuing interest because of what were believed to be its earthshattering political and economic implications [2, 45, 106]. As will be discussed, it has provoked many anxieties about its implications for participants, third parties, and the international order. This is not surprisingly given the BRI's estimated (often exaggerated) financial scale, the number of regions, countries, and actors involved, its geographic scope, and the fact the SREB and MSRI are seen as a signature initiative of President Xi's, with the BRI incorporated into the Chinese constitution, no less!

It would be false to say "academic" materials on the BRI are sparse. ${ }^{1}$ Indeed, searches of various university library catalogs and Google Scholar indicate there are thousands of BRI-related academic articles, books, briefs, conference papers, and reports, with, in the words of one writer, "scholars dancing to China's tune" soon after the promulgation of the BRI in Kazakhstan and the MSRI in Indonesia [119]. As far as books are concerned, the vast majority are edited volumes, typically involving scholars from multiple countries and/or disciplines [90, 99, 102, 125, 132, 143]. Quantity, though, does not equate to quality. An extensive review of the BRI literature reveals many studies suffer from some very serious problems. ${ }^{2}$ To list a few (many discussed later below), researchers seem stuck on a road to nowhere or in an infinite loop, meaning newer works frequently offer nothing new or keep exploring the same questionable topics. ${ }^{3}$ In addition, collective research projects are not coordinated or synchronized. Furthermore, lines of analysis are proliferating rather than optimizing, with studies covering an increasing number of topics, rather than delving into topics indepth. Moreover, BRI participants are regularly related to the role of a bit player in many analyses. As well, research often is disconnected from other literatures, quite ironic given the most prominent aspect of the BRI is connectivity. This article's purpose is to review and critique the BRI literature, with focus on academic works (particularly from political science and international relations) between 2016 and 2020. More importantly, it offers suggestions for improving the literature on the BRI and identifies several promising research directions.

\footnotetext{
${ }^{1}$ Herein, "academic" includes not only research pieces by scholars, but also think tank reports and works by researchers at international government organizations (IGOs) such as the World Bank.

${ }^{2}$ I have examined more than 200+ articles, books, and reports as the organizer of five conferences and workshops on the MSRI, the editor of three books and three special journal issues on the MSRI; the author or co-author of numerous articles and book chapters relating to the MSRI and/or SREB, and a reviewer of many BRI-focused journal and book submissions.

${ }^{3}$ Many writers make the claim that BRI-topic XYZ has not been adequately studied to justify their research. This claim, however, often reflects a failure by the relevant researcher to exploit the extant literature rather than the existence of a genuine empirical or analytical lacuna.
} 
It is critical to put BRI studies back on the right track before the credibility of this line of research is undermined and because high-quality BRI research has substantial value for academics, businesspeople, and policymakers. Regarding the latter point, all three groups have an interest in knowing what actually is transpiring. As for academics, well-done analyses can inform debates in comparative politics, foreign policy, geopolitics, international business, and the political economy of national security (PENS), among others. In addition, richer studies can give China specialists a better understanding of inter alia the drivers of Chinese foreign policy, the role and impact of domestic actors such as state-owned enterprises (SOEs) or provinces, the political impact of Chinese economic ties with others, China's effect on regional and global governance, Chinese soft power, China's impact on global finance, investment, and trade, and China's future place in global power structures. Turning to businesspeople and policymakers, they need to know what is facilitating or impeding project implementation so that they are more aware of how to enhance or accelerate progress or, if they opposed to the BRI, how to slow or block it. Furthermore, they require information about the benefits and costs associated with MSRI and SREB endeavors since such information can enable better understandings about the ultimately impact of the BRI. Beyond this, their planning and programs profit from knowledge about the actual impact of BRI initiatives on participant and third-party domestic and international economic and political policies.

In lieu of findings, which appear throughout this article, I would like to highlight five of the various recommendations present in this piece. First, BRI analysts should focus on the MSRI or SREB in specific regions or countries. At a minimum, this will allow for more careful identification of MSRI and SREB participants and projects and more in-depth treatments of the situation on the ground. Second, BRI researchers should focus on the implementation issue (i.e., the issue of MSRI and SREB project implementation), project effects (i.e., the economic and political costs and benefits of unfinished, modified, completed, or terminated projects), and the translation issue (i.e., the domestic and foreign policy effects of projects) and do work that goes beyond the usual suspects. On a related note, they need to identify, more precisely, participants and projects, undertake causal analysis, and take into account countervailing factors. Third, BRI studies need to make more extensive use of the Chinese foreign policy literature. Fourth, BRI works focused on topics like soft power need to improve variable conceptualization and operationalization and deliver more nuanced analyses. Finally, BRI studies, especially by area specialists, should take the area, not the China, perspective.

This article consists of eight sections. The next (second) section looks at commentary on general BRI themes. Another overview of the BRI is not needed since they are widely available $[5,15,89,141,147]$. The third highlights some of the potholes that works on the BRI, especially edited volumes on the BRI, seem to be hitting. The fourth through sixth sections delve into areas that should represent the core of the BRI research agenda since researching them is critical for understanding the BRI's progress and ramifications. The fourth concentrates on the "implementation" issue, noting some avenues researchers have explored and where they might head. The fifth tackles the "project effects" issue, examining areas that analysts have studied and what can be done. The sixth focuses on the "translation effects" issue. The seventh describes a myriad of hot BRI research themes, identifies their limits and specifies areas to pump 
up the quality of work. The eighth represents the conclusion. It summarizes the piece, specifies some of the policy and theoretical relevance of the article, and offers some concluding remarks.

\section{The Baffling BRI}

When China first announced the BRI, it was vague about its purpose. Not surprisingly, then, analysts spent considerable time speculating about its "true" rationales [36, 44, 69, 110, 114]. For some, it is borne out of China's domestic economic needs which include bigger markets, improved resource security, and opportunities for Chinese multinational corporations (MNCs) [5, 20, 35, 43, 126, 130, 141]. For others, it represents a PRC quest to dominate Eurasia, the global order, or standards [20, 81, 126, 133, 141]. In contrast, some have painted the BRI as a device to build relationships and reduce instability abroad $[5,20$, 130]. For yet others, it is a soft power endeavor $[35,66,150]$. There are those that have pointed to its domestic political value such as overcoming parochial provincial actors or building Xi's legacy [56, 138, 139, 141]. Given no researchers, at least to this author's knowledge, have had the opportunity to interview Xi, with whom the BRI is intimately associated, peruse PRC Chinese Communist Party (CCP) Politburo Standing Committee minutes, or sit in on meetings leading to the drafting of the "Visions and Actions on Jointly Building Silk Road Economic Belt and 21st_Century Maritime Silk Road" (hereinafter "Visions and Actions") it is puzzling some are so confident as to attribute the BRI to one or several rationales [105]. While contemporary Chinese foreign policy making is, by all accounts, very top down, multiple motives likely drive the BRI even if the initiative is entirely Xi's given he runs a huge country with innumerable needs and, like many leaders, has many goals. Even when multiple goals are enumerated, we are too often told, at length, exactly the same things others have noted for years $[3,30,107]$. It should be questioned if there is value to this. After all, the BRI evolves, insider leaks are absent, and the BRI will have effects regardless of China's "real" intentions due to the actions of Chinese MNCs, BRI participants, and various politico-economic dynamics [52, 70, 100]. Regarding this last point, it is, as the PRC is fond of saying, a symphony, not a solo [32].

Another common line of inquiry for those researching the BRI is whether or not it truly represents anything "new." For many it does not. We are told that it builds upon China's previous development initiatives for its west and southwest, that it draws upon transportation corridor schemes for Central or South Asia, that it advances other Chinese policy doctrines such as Jiang Zemin “s “Going Out” (走出去) policy, or that it simply rebrands many projects already under way or, in some cases, already completed [63, 67, 74, 93, 126]. For others, it is indeed new because of its ambitiousness, the signal it sends that the "keep a low profile and bide your time" (蹈光养晦) principle is dead, or the fact it represents a new grand strategic narrative [51, 100]. Regardless what is the case, it can be questioned if the amount of ink spilt on this issue illuminates much given BRI participants are drawn to and other parties anxious about the BRI for reasons having nothing to do with its newness or lack thereof. Moreover, one would be hard pressed to show the BRI's newness (or not) affects its realization or subsequent effects.

The amount of money the BRI involves is rarely debated, but routinely asserted. Figures range from the hundreds of billions of dollars to USD \$1 to \$4 trillion and even 
the astounding sum of $\$ 8$ trillion. One would search in vain, though, to locate a detailed breakdown of the MSRI and SREB components totaling to such sums. Worse, commentators seem to use terms such as costs, financing, and foreign direct investment (FDI) interchangeably, even though $\$ 1$ trillion of costs, loans, or FDI hardly are the same $[48,77,103]$. In any event, conventional practice is to cite the following entities as the sources of the massive funding required to implement the BRI: China's foreign currency reserve war chest, Chinese policy banks such as China Development Bank and China Export-Import Bank (China Ex-Im Bank), Chinese SOEs such as the Industrial and Commercial Bank of China (ICBC), the Silk Road Fund, the China Investment Corporation (CIC), and, last but not least, the Asian Infrastructure Investment Bank (AIIB) $[15,23,63,122,141]$. The problem with this "laundry list" is the fact that it often is ignored that these sources are not freely exploitable (this is the case with China's foreign currency reserves); have proffered statements of intent rather than concrete commitments to fund BRI projects (e.g., ICBC); or have many other emphases besides the BRI (e.g., the AIIB) [71]. The "funding" issue is not a small one. A "smaller" BRI is likely to raise far less worries as an immense one. A smaller BRI ceteris paribus is more likely to be implemented than a huge one. And a smaller BRI ceteris paribus will have different ramifications than a large one.

For several years, it was a relatively simple matter to identify all BRI countries. Authoritative documents such as the "Visions and Actions" listed their names. Key Chinese decisionmakers highlighted them in public statements or treated them as BRI participants at high-level meetings. They signed BRI cooperation agreements or were noted on lists of BRI participants by leading Chinese think tanks. Scholars found BRI maps with dots in or lines to them. China Belt and Road Forums (BRF) outcomes lists mentioned them [134]. Over time, labeling has become increasingly difficult with the expansion of the BRI to every conceivable realm such as cyberspace and every geographic realm including outer space, the Arctic, and Latin America. According to some counts, there are nearly 140 countries participating in the BRI [55]. Regardless, there are many countries such as India, Japan, and the United States (US) that do not participate in the BRI; other countries that are part of the MSRI only or the SREB only; and yet other countries like Vietnam that are but superficial BRI participants [59]. Yet insufficient attention is given to ensuring that countries are accurately categorized as MSRI or SREB participants or determining if they are meaningfully involved in the BRI.

A final general theme that almost all BRI studies address is the features of the BRI. It is widely reported that hard infrastructure such as airports, bridges, highways, railways, and seaports is an essential part of the BRI $[7,10,15,25,80]$. This is quite appropriate given the BRI's focus on connectivity. Other non-connective, but hard projects such as commercial real estate developments, mining developments, power generation facilities, satellite monitoring stations, and special economic zones (SEZs) are not infrequently deemed BRI projects, too $[40,77,87]$. Unfortunately, in treatments of the BRI generally or the BRI in specific regions or countries, no metrics are usually provided to substantiate the determination of a project as a MSRI or SREB project and it is not difficult to find studies listing any Chinese project as a BRI project. It needs to be acknowledged that "soft" infrastructureexamples include bilateral investment treaties (BIT), custom clearance agreements, civil aviation accords, free trade agreements (FTAs) - also constitutes part of the BRI [7, 23, 116, 121, 129]. After all, hard connectivity infrastructure likely will do little for flows if the legal 
and regulatory walls against them are too high. Strangely, though, there are but a few analyses of the initiation, terms, and implications of BRI BITs, FTAs, and other soft infrastructure [97].

In order to address some of the aforementioned deficiencies, researchers first should avoid looking at the BRI in its entirety. It is too big and comprehensive and highquality data absent. Instead, researchers should focus on the MSRI or the SREB. Better yet, they should focus on individual MSRI or SREB regions or MSRI or SREB countries [6, 9, 54, 78, 137]. This would allow for more precise identification of participant countries, BRI features, and the BRI's scale (i.e., costs, FDI, or loans). In tandem with or a priori to this, they need, as mentioned, to develop replicable methodologies that allows for a proper labeling of MSRI and SREB participants as well as MSRI and SREB projects [13, 14, 28]. Lastly, BRI analysts really need to revisit if it is worthwhile to persist in discussing at length the BRI's real purpose or newness when there are so many other topics (many highlighted below) that are deserving of more sustained attention.

\section{"The Bridge is Out" Problem Facing Edited Volumes}

It was pointed out earlier that edited volumes constitute the largest proportion of BRIthemed books. In concept, this is quite logical given the multitude of regions (e.g., Southeast Asia, South Asia, and Central Asia, to name a few) and types of actors (e.g., states, private security contractors), subnational actors, MNCs, international organizations) involved in the BRI. Beyond this, the BRI touches upon a myriad of issue areas such as global power structures, global governance, transportation infrastructure, global trade flows, high-speed rail, the environment, social movements, government accountability, cinema, and even wave and wind power that require diverse disciplinary expertise for proper analysis [24, 136, 140, 147, 148, 150]. Many edited volumes are quite poor, however, and not worth the time or cost. This section highlights some of the common shortcomings associated with edited volumes on the BRI, many of which afflict articles or reports on the BRI. Throughout, it also proposes various solutions, some easier to implement than others.

Too many chapters in volumes about the BRI cover exactly the same content; Viz., its origins; its configuration; features; purposes; and implications. This is problematic even if it is the case that some readers will only peruse one or a handful of chapters in some volumes. First, it limits time and space for the relevant chapter contributor to cover the areas in which he or she has expertise. Second, it devalues the book introduction, which has, among other things, the function of laying the foundation for the book. Third, it undermines the notion that an edited volume is a collective enterprise. Repairing this problem is a fairly easy matter. Editors should strongly discourage chapter writers from providing general background on the BRI in their chapters unless the writers offer new information or disagree with the facts or interpretation provided in the introduction.

Another common problem with edited volumes is that chapters frequently fail to contemplate the same analytical or empirical issues or do so superficially $[31,85,88$, $115,128,132,142]$. Of course, not every case allows this and a volume that addresses multiple themes can reach a broader audience. However, when there is a missing 
bridge - as represented by a dearth of focus on similar themes - between chapters, the potential for edited volumes to patch (definitively) gaps in empirical or theoretical knowledge is much reduced. As the editor of multiple MSRI publications, I fully appreciate being an editor can be a thankless task. However, if editors care about the value of their work for advancing BRI studies, they need to push chapter contributors onto similar tracks - going as far as providing detailed, focused checklists of appropriate themes throughout the process - and to ensure that chapter authors address these themes.

An issue related to the one noted above is that chapters almost never speak to one another. Indeed, one can scan hundreds of pages in some books and not find a single instance where one chapter cites another chapter or comments on material in another chapter. This happens even when the same theme, region, or country is examined [3, $22,47,118,120]$. This problem of nodes rather than networks, to use BRI-type terminology, as with the first shortcoming noted in this section, undermines the collective enterprise that an edited book represents, hinders knowledge accumulation, and prevents the heuristic benefits that might flow from such engagement (e.g., increased awareness of areas of disagreement or relevant explanatory factors). In an ideal world, contributors would read all the other chapters in an edited volume and engage with them. This, frankly, is not realistic so editors should spend time building such bridges themselves, inserting citations or material in other chapters (with contributor approval of course) that helps to ensure that chapters will, in some measure, speak to one another.

There are sundry other problems commonly witnessed in edited volumes on the BRI. One is the failure to update chapters that flowed from papers presented at a conference or workshop [39]. This means, in some instances, readers will be reading facts and figures that are not just two to three years old (a common turnaround time for many edited volumes), but three to five years old since conference or workshop papers themselves often are not be based on the most current information. A second is the absence of a serious effort to define key terms such as economic development, global governance, or regionalism, even when the central focus of a book is the BRI and one of these or another concept $[29,148]$. This results in publications where contributors are not talking about the same thing, limiting comparative analysis and knowledge accumulation. Certainly, many concepts are contested and contributors may not agree with the editor's conceptualization, but this cannot be assumed prima facie. Moreover, the failure to specify definitions in individual chapters (when appropriate) foregoes the learning opportunities that flow from disagreements. A third issue worth highlighting is that some edited volumes have no proper introduction or conclusion [3, 30, 39]. Indeed, some introductions will provide chapter abstracts without any effort to highlight common themes, areas of disagreement, or future research directions implied by the contributions in the edited volume.

To some extent, the aforementioned problems associated with edited volumes about the BRI are challenges confronting all edited volumes. We should not be so quick to dismiss them, however. As highlighted in this essay, the BRI literature and the BRI itself offer a set of common themes that provide a solid basis for surmounting some of the pathologies of edited volumes. 


\section{The Implementation Issue}

The implementation issue encompasses two sub-issues. First, what actually is happening with respect to MSRI and SREB projects. Second, what are the domestic and international political and economic factors, among others that have facilitated or blocked their completion or resulted in project transformations. Knowledge about the former is absolutely essential for making proper judgements about the progress of the MSRI and/or SREB. A deep understanding of the latter facilitates explanations of the state of the MSRI/SREB and permits reasoned forecasts about where the MSRI and/or SREB will head in regard to particular sectors, countries, or regions.

As for what is happening, there are too many BRI analyses drawn to the same set of cases-e.g., the high-speed railway in Laos, Gwadar Port in Pakistan, and Hambantota Port in Sri Lanka - as if that was sufficient to understand the state of affairs with respect to all projects in those countries or the situation with respect to the entire MSRI or SREB in particular regions or globally. There also are too many treatments which assume newspaper headlines, Memorandums of Understanding (MoU), and joint communiqués or public statements represent reality. Even if there is an actual project associated with these sources of information, it is not uncommon to find research that improperly distinguishes between costs, funding, and requirements. To illustrate, some analysts equate project costs or loans to FDI. Furthermore, quite a few studies are plagued by the questionable assumption that projects automatically will come to fruition even though numerous articles, book chapters, and think tank publications make clear this is not the case. To be fair, it should be noted that one can find studies that suffer from the opposite problem, which is to assume a project will not happen merely because of a negative headline, public statement, or a report of societal opposition. This happened after Mahathir Mohamad began Malaysian Prime Minister (for the second time) in 2018 and "terminated" a number of BRI projects including some pipelines and the East Coast Rail Link. As for causal analysis, it is often absent. Unfortunately, those studies that undertake it frequently are superficial. They do not consider systematically dynamics within the BRI participant state (typically analysts pay homage to "domestic politics" without actually investigating it), isolate factors having a greater causal import, or consider the role played by contextual factors.

To improve investigations of the implementation issue, five steps can be followed beyond classifying MSRI and SREB projects more carefully and looking at a more comprehensive range of projects. First, as for providing accurate information about the BRI, the proverbial 1st Mover Advantage often is not. It often is desirable to wait to see how projects develop or how news stories unfold before making conclusions about the state of the MSRI or SREB. Second, researchers should consider if the situation on the ground tracks with expectations [10, 13, 61, 113, 135]. Third, following in others' tracks, BRI observers should strive to explain why witnessed outcomes obtain and why they have departed from or exceeded expectations [27, 28, 41, 93, 104]. Fourth, BRI analysts should give due attention to BRI participant dynamics (e.g., state characteristics and domestic politics within the state) and context (e.g., regional or global political or economic dynamics) when engaging in explanation [11, 18, 54, 58, 98]. Fifth, to the extent possible, researchers should attempt to isolate which variables have the greatest causal impact on project advancement. 


\section{The Project Effects Issue}

As mentioned, the project effects issue pertains to the direct and indirect benefits and costs of the BRI. These can be global, regional, sub-regional, national, or sub-national. Illustrations of potential benefits include increased economic growth, higher trade levels, better infrastructure, industrialization, greater productivity, technology transfer, higher energy production and better energy availability, job creation, poverty alleviation, reduced transportation costs and times, and regional economic integration $[33,57$, 64, 92, 94, 109]. Understudied potential costs include higher trade deficits, de-industrialization, FDI displacement, increased competition for local business, the abrogation of sovereignty, the loss of domestic and foreign policy independence, increased pollution or environmental degradation, or social dislocation $[65,77,131]$. These issues are not just of interest to economists, development specialists, environmental scientists, international business scholars, or infrastructure experts. They merit the attention of those specializing in political science, international relations, and related disciplines. Knowing the benefits and costs associated with BRI projects helps us judge if BRI effects, on balance, track with the BRI's high-minded rhetoric. Such information also can illuminate which BRI projects should be embraced or adjusted, where mitigation measures are required, and what political and/other factors influence the costs and benefits of BRI projects. Finally, it aids us in better understanding the actual "stimuli" confronting the decisionmakers in BRI participant countries when they make their domestic and foreign policy choices (a topic soon to be addressed).

A fair proportion of studies about BRI project effects are not about the effects of specific projects, but rather statistical analysis, largely by economists or business specialists, about the prospective benefits of the BRI writ large [38, 42, 50, 91, 108]. Such studies typically have three shortcomings. First, they take it for granted that BRI projects will be completed as planned $[38,50,79]$. Second, given data limitations, they often are based on short time frames or use debatable proxies for unavailable data [42]. Third, numerous studies lack sufficient control variables or awareness of the actual setting on the ground. Regarding the latter, one analysis assumes India and Vietnam are BRI participants, which is wrong with respect to the former and problematic (as noted) with respect to the latter. As for qualitative studies, they rarely analyze comprehensively or comparatively the benefits of BRI projects. They do highlight, among other things, job creation, training, technology transfer, connectivity, and industrialization associated with BRI projects. Industry sector, country, or region wide studies are rare. Moreover, only a few give the distribution of benefits attention [51, 72, 79, 96, 101]. I am not aware of any large-N studies that look at the costs of the BRI in terms of increasing trade deficits, promoting deindustrialization, or promoting sectoral lock-in. In contrast, there are many qualitative studies that highlight downsides associated with the BRI. As with case studies that look at positives, analyses of costs usually draw upon a handful of cases. We are informed of environmental problems along the Mekong, Cambodia's reduced foreign policy autonomy, Sri Lanka's loss of sovereignty; land seizures in Ethiopia, and the abuse of unions or failure to use local labor in Greece and Saipan $[18,34,58,73,131]$. Ultimately, though, we obtain no understanding of the BRI's total costs for a given industrial sector, country, or region.

Better work on "project effects," first and foremost, requires a clear identification of MSRI and SREB projects. Second, quantitative work needs to adopt more realistic 
assumptions, use better data sets, find ways to take into account the context, consider the costs, benefits, and limits of the BRI. Third, qualitative researchers need to consider a wider range of cases, work on producing more comprehensive studies, and consider both costs and benefits. Both qualitative and quantitative researchers need give due attention to the distribution of benefits. Lastly, both quantitative and qualitive researchers need to pay attention to the increment associated with the BRI. To illustrate, infrastructure such as hydropower and power generation projects and resource exploitation activities such as energy extraction and mining are intrinsically threatening to the environment, social groups, and government accountability. If costs are identified, it is a legitimate question to ask if the problem is the nature of the activity itself rather than the BRI, China, or Chinese MNCs per se. This is a matter of using reasonable rather than unattainable benchmarks to judge the impact of the BRI. In this vein, it might be beneficial to take a comparative look at the effects of projects by countries like Germany, Japan, or Korea, too [37].

\section{The Translation Issue}

The translation issue relates to the political effects, typically on BRI participants, of MSRI and/or SREB projects. Potential foreign policy effects might include the embrace of Beijing's China favored domestic or foreign policies, coordination with or acquiescence to China in international organizations such as the UN or Association of Southeast Asian Nations, and the dilution or termination of relations with third parties. In the past, analysts have noted countries such as Cambodia, Ethiopia, Greece, Hungary, and Sri Lanka as reflecting these dynamics [18, 58, 60, 73, 127]. Possible domestic policy effects in BRI participants could entail the promulgation of policies, laws, and regulations tailored to the needs of Chinese national actors or MNCs, the lax enforcement of regulations that might adversely affect Chinese actors, or crackdowns on groups opposing BRI projects. The core presumption in such studies is that decisionmakers are homo economicus and that the economic allure of the BRI, perhaps magnified by other trade, FDI, and aid ties with China, will prove irresistible, bringing political alignment and deference in its wake.

The PENS literature, though, has long called into question the thesis that there is a one-to-one correspondence between economic stimuli and political behavior [12, 17, 75]. After all, economic relations often entail both positive and negative economic stimuli. In addition, decisionmakers must weigh not just economic factors, but political ones at the national level (e.g., a loss of territorial integrity or national economic independence) or within their countries (e.g., a reduction in support among key constituencies). It is entirely possible these political costs may offset the political effects of positive economic stimuli. Furthermore, it is a mistake to assume that economic costs and benefits and political costs and benefits are entirely derivative of the bilateral dynamic given other countries, IGOs, and MNCs commonly acting to influence them. As for the BRI specifically, it is a mistake to assume all projects will be completed as designed and will deliver the net positive benefits, and that these net benefits have unadulterated effects on BRI participants [8, 11, 13]. Another related issue is that it is quite regularly assumed that "pro-China" behaviors are attributable to the BRI and other economic stimuli when the reality might be that other powerful 
political motives propel a country's behaviors. Such motives include a leader's desire to ensure his or her domestic political position, fend off external political pressures, or to find new security allies [18, 27, 53, 58, 80, 123].

In order to address the translation issue better, researchers need to tackle the extensively discussed implementation and project effects issues well. They need to know whether or not BRI projects have been completed and what net political and economic costs and benefits they actually deliver. They further need to investigate if there are political and economic considerations that might offset the net stimuli flowing from the BRI. On a related note, the role of third parties in shaping this calculus needs due attention. Even if researchers find a correlation between political behaviors and this BRI economic stimuli, they should not automatically assume that a BRI participant's observed foreign or domestic policy behaviors is a function of this economic stimuli. They need to probe if there might be other variables contributing to the observed behavior.

Beyond the aforementioned issues, one growing area of research that pertains to effects is the effect of the BRI on Chinese foreign and security policy. This research looks at themes like the People's Liberation Army (PLA)'s military posture, hardware acquisition activities, naval basing plans, use of private security forces, collaborations with overseas police forces, and even the development of political risk insurance [1, 26, 112]. Most studies along these lines are very "guns and bombs" oriented and could broaden their areas of investigation to other realms such as how the BRI has or has not influenced how China prioritizes regions or countries, how it has affected tenor and content of Chinese diplomacy, and how it has reshaped CCP committees or government ministries. Regarding the last point, we know for example that China has created a CCP small group on the BRI. We also know that it has created a governmental coordinating body [56]. However, there has been no research on the operations of these bodies or their impact on BRI policy specifically or Chinese foreign policy more generally. This research tends to be highly descriptive and, indeed, often speculative, and the tools are not provided to judge either what is likely to transpire or what the ultimate implications of what transpires actually will be.

\section{Roads Needing Further Travel}

Earlier I noted the problem of lines of analysis proliferating rather than optimizing. While advocating that researchers concentrate their energies on the implementation, effects, and translation issues discussed above and also believing that BRI analysts should avoid trying to cover too many BRI topics (which prevents knowledge accumulation), there are several roads that need to be further traveled, partly because, to mix metaphors, the ship has already sailed with numerous articles, books, and think tank reports on these themes already having appeared. One route is the study of Chinese subnational and nonstate actors involved in the BRI. A second ties to the analysis of Chinese foreign policy. A third relates to research on the BRI and PRC soft power. A fourth pertains to the study of the BRI, China, and global governance. The fifth links to the study of the BRI (and China) in the context of certain countries or regions. Another, which I do not discuss below due to space constraints and a desire for focus, is more work comparing China's BRI to the infrastructure endeavors of other countries. Journeying along these routes has the value not only of enhancing our knowledge about the MSRI and SREB, but also should enrich debates about Chinese policy 
making, the drivers of Chinese foreign policy, the factors shaping Chinese outward FDI, Chinese soft power, and China's impact on international and regional orders.

As many have observed, there are multiple actors involved in the BRI [5, 56, 124]. Focusing just on China, these include Chinese ministries, Chinese policy banks, the PLA, Chinese subnational actors such as provinces and cities, and Chinese MNCSs, both SOEs and private. There is almost no work examining carefully the role played by these entities in influencing the BRI projects, geographic areas (inside and outside China), and MSRI and SREB realms (e.g., energy, telecommunications, or transportation) that get attention, the specific policies and projects that are embraced in particular BRI regions or countries, and the implementation of BRI policies and projects. We also lack information about how disagreements are resolved, players supervised, and policy problems rectified. Admittedly, these areas are not easy to investigate given the opaque nature of the PRC government and the CCP. Regardless, it should be possible to obtain data with respect to some of these dynamics. Indeed, the ship may be coming in areas such as the study of Chinese subnational actors and MNCs and the BRI $[82,83,86]$.

There is a very rich and large body of theoretical work on Chinese foreign policy. It tries to identify the players shaping Chinese foreign policy; contemplates the extent to which individual-level factors such as ideology, culture, and perceptions matter; ponders the impact of domestic factors such as Chinese state-capitalism, Chinese nationalism, factions, the PLA, and Chinese public opinion; looks at the role of systemic factors such as international power balances, global norms, and international organizations; and assesses the salience of China's historical relations with the relevant counterparty, economic interdependencies, and CCP-to-counterparty ties [4, 68, 76, 111, 144-146]. This literature, however, is almost entirely invisible as far as BRI studies are concerned. This needs to change not just because, as implied above, an opportunity is foregone to enrich existing debates, but also because past theoretical work can help researchers identify variables that matter in particular BRI cases. Furthermore, one can use these existing theoretical tools to explain outcomes witnessed in particular MSRI and SREB cases.

Turning to the issue of soft power, it seems to be taken for granted that the BRI will deliver increased soft power for China. While the logic rarely is made explicit, the thinking seems to be that the BRI casts China in the light of an economic benefactor, a great power, or public goods provider and thus will bolster is image. Alternatively, those in a country receiving BRI FDI or a BRI project will view China more positively because of the scale of such projects, the evidence projects give to China's ability to "get things done" at low cost and quickly, and the legitimacy ruling elites derive from the BRI which allows them to deliver political and economic goods to supporters and their publics. As with studies about Chinese foreign policy, there is a voluminous literature on Chinese soft power. One would not know this, though, from perusing commentary on China, the BRI, and soft power. In any event, those studying this topic need to, at a minimum, be attentive to the following: the precise conceptualization of soft power, the development of measures to operationalize it, the aggregation of soft power effects (which have positive and negative elements), the refined identification of soft power targets, and the precise measurement of attitudinal change that actually takes place and its foreign policy effects [16].

China, the BRI, and global governance is another topic garnering continuing attention. The predominant object of study to date for those studying this theme has 
been the AIIB and its formation. Putting aside the issue of whether or not the AIIB really is a BRI bank (something that has not been proven), many analysts do not spend the time to investigate if and how much the AIIB's norms or structures actually challenge the existing global order. Indeed, some have shown the challenge is not so great [84]. More generally, a very serious issue with studies in this vein is that a large proportion lacks a conceptualization and/or operationalization of the term global governance. Beyond this, empirical work needs substantial improvement. It often is implied the BRI is notably affecting global standards based on weak proof such as a China Daily story that some railway has used "Chinese" hardware, technologies, and standards or an aspirational statement by a Chinese official that China will use the BRI to promote Chinese standards [20, 49, 95]. Finally, given that the subject of global governance is huge covering IGOs, international law, and international norms in realms such as lending principles, environmental protection, arms proliferation, international labor standards, and tax, researchers should be cautious about leaping to the conclusion that what transpires in one realm is indicative of what is transpiring in all. Yet again, focused studies may be better than grand sweeping ones.

The BRI has its origins in China; China is the locomotive of the project; and China is the BRI's track designer, layer, and financier. It does not surprise, therefore, that most write about the BRI from the China perspective, highlighting China's goals, China's funding mechanisms, and the BRI map according to China. Indeed, where the BRI is concerned, it would be fair to say that "everyone's a China specialist." There are many intriguing tracts by those with expertise in Southeast Asia, South Asia, Central Asia, Africa, and the Middle East yet often there is little in-depth and/or systematic analysis of the goals of BRI participants in these regions, the domestic and international political and economic factors that drive decisionmakers in these countries to embrace and implement the BRI, and how the embrace and/or implementation of the BRI actually has affected participant foreign and domestic policies (the "project effects" issue noted earlier) [46, 62, 117]. This is disheartening because such area specialists have, in concept, the ability to interview participants and exploit local government documents and media sources in a way that China specialists cannot. Moreover, they presumably have an awareness of a BRI participant culture, history, language, and/or context that should enrich our understanding of what is transpiring beyond what a China specialist could do. The point is hardly that area specialists cannot take the China perspective, but rather that it is desirable to see more pieces such as Africa in the BRI which are largely about the latter and not the former. This way area specialists can exploit connectivities or their comparative advantages.

\section{Conclusion}

One goal of this article has been to review and critique the academic literature on the BRI which continues chugging along, but is at risk of a wreck for reasons extensively detailed above [21]. A more important purpose is to get the literature on the BRI headed in a more fruitful direction yielding greater wins. This article began by reflecting on coverage of some general BRI themes, concluding with some thoughts about ways to address shortcomings in this coverage. It then turned to a treatment of problems frequently associated with edited volumes on the BRI, offering suggestions about how these defects might be surmounted. Following this it delved into the 
implementation issue, a theme commonly addressed, albeit not necessarily well. In tandem, it noted some ideas for improving research on this topic. The next section of the article tackled the project effects issue, enumerated various deficiencies seen in related research, and identified various routes to enhance the literature. Subsequently, the article looked at the translation issue and stressed the need to make use of insights from the PENS literature to produce more informative analyses. The final section looked at several hot areas in the BRI studies field, some of their limitations, and steps that might be taken to ensure smoothly sailing. In the balance of this section, I look at this article's policy and theoretical relevance and then end with some final observations.

This review and critique is relevant for policymakers because it demonstrates that the literature on the BRI still has substantial limitations. In light of this, decisionmakers and policy analysts should be careful about relying unreservedly on all or a subset of the literature to make judgements about the progress of MSRI and SREB projects, the political and economic effects flowing from these projects, and the domestic and foreign policy implications of these effects. More importantly, if circumstances allow, they should avoid making significant policy choices unless they have access to highquality studies or have taken into account fully the shortcomings detailed in this piece. As far as businesspeople are concerned, the same cautions apply. They should avoid consequential trade, investment, and operational decisions unless they can exploit analyses which avoid the enumerated defects or they are fully cognizant of the literature's limits. As for scholars, the implications of this article are both positive and negative. The positive is that there remain many routes where analysts can embark on more rigorous studies. The negative is that, like the BRI, much hard work will be needed to bring research projects to full fruition with all the attendant benefits.

The progress of the BRI has become bumpier, even though it continues to move forward slowly [19]. This is the case for BRI research, too. There are "conductors" as far as BRI research is concerned, but many publishers, journal and book editors, and reviewers seem more content with an increasing number of passengers rather than making sure the research train ends up at its desired destination. The full benefits of BRI research, however, only will be realized when there is more focused study, more attention to the infrastructure underpinning social science analysis, better project data gathering, more connections along the various pathways that analysts have embarked, and the full use of existing tracks from the diverse realms the BRI encompasses.

Acknowledgements The author would like to thank Jonathan Fulton, Wei Liang, and Jessica Teets for their feedback on various drafts as well as journal reviewers for their helpful comments.

Open Access This article is licensed under a Creative Commons Attribution 4.0 International License, which permits use, sharing, adaptation, distribution and reproduction in any medium or format, as long as you give appropriate credit to the original author(s) and the source, provide a link to the Creative Commons licence, and indicate if changes were made. The images or other third party material in this article are included in the article's Creative Commons licence, unless indicated otherwise in a credit line to the material. If material is not included in the article's Creative Commons licence and your intended use is not permitted by statutory regulation or exceeds the permitted use, you will need to obtain permission directly from the copyright holder. To view a copy of this licence, visit http://creativecommons.org/licenses/by/4.0/. 


\section{References}

1. Arduino, Alessandro, and Gong Xue, eds. 2018. Securing the Belt and Road Initiative: Risk Assessment, Private Security, and Special Insurances along the New Wave of Chinese Outbound Investments. Singapore: Palgrave MacMillan.

2. Berke, Robert. 2015. China's New Silk Road Could Change Global Economics Forever. Business Insider, May 22. http://www.businessinsider.com/chinas-new-silk-road-could-change-globaleconomics-forever-2015-5

3. Berlie, Jean A., ed. 2020. China's Globalization and the Belt and Road Initiative. Cham: Palgrave MacMillan.

4. Blanchard, Jean-Marc F. 2015. The People's Republic of China leadership transition and its external relations: still searching for definitive answers. Journal of Chinese Political Science 20 (1): 1-16.

5. Blanchard, Jean-Marc F. 2017. Probing China's 21st century maritime silk road initiative (MSRI): An examination of MSRI narratives. Geopolitics 22 (2): 246-268.

6. Blanchard, Jean-Marc F., ed. 2018. China's Maritime Silk Road and South Asia. Singapore: Palgrave MacMillan.

7. Blanchard, Jean-Marc F. 2018. China's Twenty-First Century Maritime Silk Road Initiative and South Asia: Political and Economic Contours, Challenges, and Conundrums. In China's Maritime Silk Road and South Asia, ed. Jean-Marc F. Blanchard. Singapore: Palgrave MacMillan, 1-31.

8. Blanchard, Jean-Marc F. 2018. China's maritime silk road initiative (MSRI) and Southeast Asia: A Chinese 'pond' not 'Lake' in the works. Journal of Contemporary China 27 (111): 329-343.

9. Blanchard, Jean-Marc F., ed. 2019. China’s 21st Century Maritime Silk Road Initiative and Southeast Asia. Singapore: Palgrave MacMillan.

10. Blanchard, Jean-Marc F. 2019. China's MSRI in Southeast Asia: Dynamism amidst the Delays, Doubts, and Dilemmas." In China's 21st Century Maritime Silk Road Initiative and Southeast Asia, ed. JeanMarc F. Blanchard. Singapore: Palgrave MacMillan, 1-34.

11. Blanchard, Jean-Marc F. 2019. Malaysia and China's MSRI: The Road to China was Taken before the (Maritime Silk) Road was Built. In China's 21st Century Maritime Silk Road Initiative and Southeast Asia, ed. Jean-Marc F. Blanchard. Singapore: Palgrave MacMillan, 95-132.

12. Blanchard, Jean-Marc F. 2019. Brazil's Samba with China: Economics brought them closer, but failed to ensure their tango. Journal of Chinese Political Science 24 (4): 583-603.

13. Blanchard, Jean-Marc F. 2020. Problematic prognostications about China's maritime silk road initiative (MSRI): Lessons from Africa and the Middle East. Journal of Contemporary China 29 (122): 159-174.

14. Blanchard, Jean-Marc F. 2021. China's MSRI in Africa and the Middle East: Political Economic Realities Continue to Shape Results and Ramifications. In China's Maritime Silk Road, Africa, and the Middle East, ed. Jean-Marc F. Blanchard. Singapore: Palgrave MacMillan.

15. Blanchard, Jean-Marc F., and Colin Flint. 2017. The Geopolitics of China's Maritime Silk Road Initiative. Geopolitics 22 (2): 223-245.

16. Blanchard, Jean-Marc F., and Fujian Lu. 2012. Thinking hard about soft power: A review and critique of the literature on China and soft power. Asian Perspective 36 (4): 565-589.

17. Blanchard, Jean-Marc F., and Norrin M. Ripsman. 2013. Economic Statecraft and Foreign Policy: Sanctions and Incentives and Target State Calculations. London: Routledge.

18. Blanchard, Jean-Marc F. and Edson Ziso. 2021. The Maritime Silk Road Initiative and Ethiopia: Transforming Policies, Institutions, and Politics in Expected and Unexpected Ways. In China's Maritime Silk Road, Africa, and the Middle East, ed. Jean-Marc F. Blanchard. Singapore: Palgrave MacMillan.

19. Bradsher, Keith. 2020. China Renews Its 'Belt and Road' Push for Global Sway. The New York Times, January 15. https://www.nytimes.com/2020/01/15/business/china-belt-and-road.html

20. Cai, Peter. 2017. Understanding China's Belt and Road Initiative. Lowy Institute for International Policy, March 22. https://www.lowyinstitute.org/publications/understanding-belt-and-road-initiative

21. Cao, Mingchun, and Ilan Alon. 2020. Intellectual structure of the belt and road initiative research: A scientometric analysis and suggestions for a future research agenda. Sustainability 12 (17): 1-41.

22. Carrai, Maria A., Jean-Christophe Defraigne, and Jan Wouters, eds. 2020. The Belt and Road Initiative and Global Governance. Cheltenham: Edward Elgar Publishing.

23. Chaisse, Julien, and Mitsuo Matsushita. 2018. China's 'belt and road' initiative: Mapping the world trade normative and strategic implications. Journal of World Trade 52 (1): 163-186.

24. Chan, Debby Sze Wan and Ngai Pun. 2021 forthcoming. Renegotiating belt and road cooperation: Social resistance in a Sino-Myanmar copper mine. Third World Quarterly. 
25. Chan, Gerald. 2018. Understanding China's New Diplomacy: Silk Roads and Bullet Trains. Cheltenham: Edward Elgar.

26. Chang, Yen-Chiang. 2018. The ' $21^{\text {st }}$ century maritime silk road initiative' and naval diplomacy in China. Ocean \& Coastal Management 153 (1): 148-156.

27. Chaziza, Mordechai. 2021. Egypt in China's Maritime Silk Road Initiative: Relations Cannot Surmount Realities. In China's Maritime Silk Road, Africa, and the Middle East, ed. Jean-Marc F. Blanchard. Singapore: Palgrave MacMillan.

28. Chen, Shaofeng. 2018. Regional responses to China's maritime silk road initiative in Southeast Asia. Journal of Contemporary China 27 (111): 344-361.

29. Cheng, Dawei. 2018. Trade Governance of the Belt and Road Initiative: Economic Logic, Value Choices, and Institutional Arrangement. London: Routledge.

30. Cheng, Yu, Lilei Song, and Lihe Huang, eds. 2018. The Belt \& Road Initiative in the Global Arena. Singapore: Palgrave MacMillan.

31. Cheung, Fanny M., and Ying-yi Hong, eds. 2018. Regional Connection under the Belt and Road Initiative: The Prospects for Economic and Financial Cooperation. London: Routledge.

32. China Daily. 2015. China's Belt and Road Initiatives Not Solo, but Symphony, March 8. http://www. chinadaily.com.cn/business/2015-03/08/content_19750844.htm

33. China Daily. 2019. BRI-Related Economic Trade Cooperation Zones Create 300,000 Local Jobs, April 6. http://www.chinadaily.com.cn/a/201904/06/WS5ca89f3ca3104842260b4a84.html

34. China File. 2017. Is Chinese Investment Good for Workers, December 13. https://www.chinafile.com/ conversation/chinese-investment-good-workers

35. Clarke, Michael. 2017. The belt and road initiative: China's new grand strategy? Asia Policy 24: 71-79.

36. Clarke, Michael. 2018. The belt and road initiative: Exploring Beijing's motivations and challenges for its new silk road. Strategic Analysis 42 (2): 84-102.

37. Dadabaev, Timur. 2018. Japanese and Chinese infrastructure development strategies in Central Asia. Japanese Journal of Political Science 19 (3): 542-561.

38. de Soyres, Francois, Alen Mulabic, Siobhan Murray, Nadia Rocha, and Michele Ruta. 2018. How Much Will the Belt and Road Initiative Reduce Trade Costs? World Bank Policy Research Working Paper 8614.

39. Deepak, B.R., ed. 2018. China's global rebalancing and the new silk road. Singapore: Springer.

40. Demissie, Alexander. 2018. Special Economic Zones: Integrating African Countries in China's Belt and Road Initiative." In Rethinking the Silk Road: China's Belt and Road Initiative and Emerging Eurasian Relations, ed. Maximilian Mayer. Singapore: Palgrave Macmillan, 69-84.

41. Dorraj, Manochehr and Jean-Marc F. Blanchard. 2021. Iran in China's Maritime Silk Road initiative (MSRI): Bounded Progress and Bounded Promise. In China's Maritime Silk Road, Africa, and the Middle East, ed. Jean-Marc F. Blanchard. Singapore: Palgrave MacMillan.

42. Du, Julan, and Yifei Zhang. 2018. Does one belt one road initiative promote Chinese overseas direct investment? China Economic Review 47: 189-205.

43. Du, Michael M. 2016. China's 'one belt, one road' initiative: Context, focus, institutions, and implications. The Chinese Journal of Global Governance 2: 30-43.

44. Dunford, Michael, and Weidong Liu. 2019. Chinese perspectives on the belt and road initiative. Cambridge Journal of Regions, Economy and Society 12 (1): 145-167.

45. Economist. 2018. China's Belt-And-Road Plans Are to Be Welcomed-and Worried About, July 26. https://www.economist.com/leaders/2018/07/26/chinas-belt-and-road-plans-are-to-be-welcomed-andworried-about

46. Ehizuelen, Michael Mitchell Omoruyi. 2017. More African countries on the route: The positive and negative impacts of the belt and road initiative. Transnational Corporations Review 9 (4): 341-359.

47. Ehteshami, Anoushiravan, and Niv Horesh, eds. 2018. China's Presence in the Middle East: The Implications of the One Belt, One Road Initiative. Abingdon: Routledge.

48. Eisenman, Joshua and Devin T. Stewart. 2017. China's New Silk Road is Getting Muddy. Foreign Policy, January 9. http://foreignpolicy.com/2017/01/09/chinas-new-silk-road-is-getting-muddy

49. Ekman, Alice, ed. 2019. China's Belt \& Road and the World: Competing Forms of Globalization," Etudes de I'Ifri, Ifri, April. https://www.ifri.org/sites/default/files/atoms/files/ekman_china_belt_road_ world_2019.pdf

50. Fan, Zhai. 2018. China's belt and road initiative: A preliminary quantitative assessment. Journal of Asian Economics 55: 84-92.

51. Fardella, Enrico, and Giorgio Prodi. 2017. The belt and road initiative impact on Europe: An Italian perspective. China \& World Economy 25 (5): 125-138. 
52. Flint, Colin, and Cuiping Zhu. 2020. The geopolitics of connectivity, cooperation, and hegemonic competition: The belt and road initiative. Geoforum 99: 95-101.

53. Fulton, Jonathan. 2020. Domestic politics as fuel for China's maritime silk road initiative: The case of the Gulf monarchies. Journal of Contemporary China 29 (122): 175-190.

54. Fulton, Jonathan, ed. 2020. Regions in the Belt and Road Initiative. Abingdon: Routledge.

55. Green Belt and Road Initiative Center. N.d. Countries of the Belt and Road Initiative (BRI). https:// green-bri.org/countries-of-the-belt-and-road-initiative-bri\#: :text=The $\% 20$ countries $\% 20$ of $\% 20$ the $\%$ 20Belt,are\%20part\%20of\%20the\%20BRI)

56. He, Baogang. 2019. The domestic politics of the belt and road initiative and its implications. Journal of Contemporary China 28 (116): 180-195.

57. He, Sophie. 2018. Infrastructure Investment in B\&R Economies 'Offers Rich Rewards.' China Daily, June 8. http://www.chinadaily.com.cn/a/201806/08/WS5b19da8ba31001b82571ed54.html

58. Heng, Pheakdey and Vannarith Chheang. 2019. The Political Economy of China's Maritime Silk Road Initiative in Cambodia. In China's 21st Century Maritime Silk Road Initiative and Southeast Asia, ed. Jean-Marc F. Blanchard. Singapore: Palgrave MacMillan, 163-190.

59. Hiep, Le Hong. 2018. The Belt and Road Initiative in Vietnam: Challenges and Prospects. ISEAS Perspective 18. https://www.iseas.edu.sg/images/pdf/ISEAS_Perspective_2018_18@50.pdf

60. Hillman, Jonathan. 2018. China's Belt and Road Initiative: Five Years Later, January 25, Statement before the U.S.-China Economic and Security Review Commission. https://www.csis.org/analysis/ chinas-belt-and-road-initiative-five-years-later- 0

61. Hillman, Jonathan. 2018. China's Belt and Road is Full of Holes. CSIS Briefs, September. https://www. csis.org/analysis/chinas-belt-and-road-full-holes

62. Hoh, Anchi. 2019. China's belt and road initiative in Central Asia and the Middle East. DOMES 28 (2): 241-276.

63. Holslag, Jonathan. 2017. How China's new silk road threatens European trade. The International Spectator 52 (1): 46-60.

64. Huang, Ge. 2019. China Leads BRI with Full tech Support. Global Times, April 19. https://www. globaltimes.cn/content/1146644.shtml

65. Hughes, Alice C. 2019. Understanding and minimizing environmental impacts of the belt and road initiative. Conservation Biology 33 (4): 883-894.

66. Jakimow, Malgorzata. 2019. 'Desecuritisation as a Soft Power Strategy', the Belt and Road Initiative, European fragmentation and China's normative influence in Central-Eastern Europe. Asia Europe Journal 17 (4): 369-385.

67. Johnson, Christopher K. 2016. President Xi Jinping's 'Belt and Road' Initiative: A Practical Assessment of the Chinese Communist Party's Roadmap for China's Global Resurgence. CSIS, March. https:// www.csis.org/analysis/president-xi-jinping\%E2\%80\%99s-belt-and-road-initiative.

68. Johnston, Alastair Ian, and Robert Ross, eds. 2006. New Directions in the Study of China's Foreign Policy. Stanford: Stanford University Press.

69. Johnston, Lauren A. 2019. The belt and road initiative: What is in it for China? Asia \& The Pacific Policy Studies 6 (1): 40-58.

70. Jones, Lee, and Jinghan Zeng. 2019. Understanding China's 'belt and road initiative:' Beyond 'grand strategy' to a state transformation analysis. Third World Quarterly 40 (8): 1415-1439.

71. Joy-Perez, Cecilia and Derek Scissors. 2018. The Chinese State Funds Belt and Road, but Does not Have Trillions to Spare. American Enterprise Institute, March. https:/www.aei.org/research-products/ report/the-chinese-state-funds-belt-and-road-but-does-not-have-trillions-to-spare

72. Kamel, Maha S. 2018. China's belt and road initiative: Implications for the Middle East. Cambridge Review of International Affairs 31 (1): 76-95.

73. Karl, David J. 2018. Sri Lanka, the Maritime Silk Road, and Sino-Indian Relations. In China's Maritime Silk Road Initiative and South Asia, ed. Jean-Marc F. Blanchard. Singapore: Palgrave MacMillan, 137172 .

74. Karrar, Hasan H. 2019. From Central Asia to the World: China's Regional Diplomacy as a Precursor for Global Connectivity. In China's Belt and Road Initiative in a Global Context, Vol. I: A Business and Management perspective, eds. Jawad Syed and Yung-Hsiang Ying. Cham: Palgrave MacMillan, 61-86.

75. Kastner, Scott. 2016. Buying influence? Assessing the political effects of China's international trade. Journal of Conflict Resolution 60 (6): 980-1007.

76. Kim, Samuel S. ed. 1989. New Directions and Old Puzzles in Chinese Foreign Policy. In China and the World: New Directions in Chinese Foreign Relations, ed. Samuel S., Kim. Boulder: Westview Press, 330 . 
77. Kliman, Daniel Rush Doshi, Kristine Lee, and Zack Cooper. 2019. Grading China's Belt and Road. CNAS, April. https:/www.cnas.org/publications/reports/beltandroad

78. Kohli, Harinder S., Johannes F. Linn, and Leo M. Zucker, eds. 2019. China's Belt and Road Initiative: Potential Transformation of Central Asia and the South Caucasus. New Delhi: Sage Publications.

79. Lall, Somik V. and Mathilde Lebrand. 2019. Who wins, who loses? Understanding the spatially differentiated effects of the belt and road initiative. World Bank Group Policy Research Working Paper 8806.

80. Lampton, David M., Selina Ho, and Cheng-Chwee Kuik. 2020. Rivers of Iron: Railroads and Chinese Power in Southeast Asia. Berkeley: University of California Press.

81. Len, Christopher. 2018. Belt and Road Initiative: Beijing's Ambition to be a Player in Global Energy Governance. China Policy Institute Analysis, March 27. http://cpianalysis.org/2018/03/27/belt-androad-initiative-beijings-ambition-to-be-a-major-player-in-global-energy-governance

82. Li, Mingjiang. 2019. China's economic power in Asia: The belt and road initiative and the local Guangxi government's role. Asian Perspective 43 (2): 273-295.

83. Li, Xiaojun, and Ka Zeng. 2019. To join or not to join? State ownership, commercial interests, and China's belt and road initiative. Pacific Affairs 92 (1): 5-26.

84. Liang, Wei. 2019. China and the 'Belt and Road Initiative' (BRI): Contested Multilateralism and Innovative Institution-Building. In Handbook on the International Political Economy of China, ed. Ka Zeng. Cheltenham: Elgar, 361-376.

85. Lim, Tai Wei, Henry Hing Lee Chan, Katherine Hui-Yi Tseng, and Wen Xin Lim. 2016. China's One Belt One Road Initiative. London: Imperial College Press.

86. Lin, Weiqiang, and Qi Ai. 2020. 'Aerial silk roads': Airport infrastructures in China's belt and road initiative. Development and Change 51 (4): 1123-1145.

87. Liu, Hong, and Guanie Lim. 2019. The political economy of a rising China in Southeast Asia: Malaysia's response to the belt and road initiative. Journal of Contemporary China 28 (116): 216-231.

88. Liu, Wei, ed. 2018. China's Belt and Road Initiatives: Economic Geography Reformation. Singapore: Springer.

89. Liu, Weidong, and Michael Dunford. 2016. Inclusive globalization: Unpacking China's belt and road initiative. Area Development and Policy 1 (3): 323-340.

90. Lo, T. Wing, Dina Siegel, and Sharon I. Kwok, eds. 2020. Organized Crime and Corruption Across Borders: Exploring the Belt and Road Initiative. Abingdon: Routledge.

91. Lu, Yue, Yunlong Lu, Zeng Ka, and Li Yadong. 2018. China's outward foreign direct investment and the margins of trade: Empirical evidence from 'one belt, one road' countries. China: An International Journal 16 (1): 129-151.

92. Malik, Ahmad Rashid. 2018. The China-Pakistan Economic Corridor (CPEC): A Game Changer for Pakistan's Economy. In China's Global Rebalancing and the New Silk Road, ed. B.R. Deepak. Singapore: Springer, 69-83.

93. Malik, J. Mohan. 2018. Myanmar's role in China's maritime silk road initiative. Journal of Contemporary China 27 (111): 362-378.

94. Maliszewska, Maryla. 2019. The Belt and Road Initiative: Economic, Poverty, and Environmental Impacts. World Bank Group Policy Research Working Paper 8814.

95. Manuel, Ryan. 2019. Twists in the Belt and Road. China Leadership Monitor, September 1. https:// www.prcleader.org/manuel-belt-road

96. Mao, Haiou, Guanchun Liu, Chengsi Zhang, and Rao Muhammad Atif. 2019. Does belt and road initiative hurt node countries? A study from export perspective. Emerging Markets Finance and Trade 55 (7): 1472-1485.

97. Martinico, Giuseppe, and Xueyan Wu, eds. 2020. A Legal Analysis of the Belt and Road Initiative: Towards a New Silk Road? Cham: Palgrave MacMillan.

98. Masabo, Conrad John. 2021. Tanzania in China's MSRI: The 'Chinese Dream' Awaits Alignment with the African One. In China's Maritime Silk Road, Africa, and the Middle East, ed. Jean-Marc F. Blanchard. Singapore: Palgrave MacMillan.

99. Mayer, Maximilian, ed. 2018. Rethinking the Silk Road: China's Belt and Road Initiative and Emerging Eurasian Relations. Singapore: Palgrave Macmillan.

100. Mayer, Maximilian. 2018. China's Rise as Eurasian Power: The Revival of the Silk Road and Its Consequences. In Rethinking the Silk Road: China's Belt and Road Initiative and Emerging Eurasian Relations, ed. Maximilian Mayer. Singapore: Palgrave Macmillan, 1-42.

101. Mboya, Cliff. 2021. The Maritime Silk Road Initiative: Connecting Africa. In China's Maritime Silk Road, Africa, and the Middle East, ed. Jean-Marc F. Blanchard. Singapore: Palgrave MacMillan. 
102. Mendes, Carmen Amado, ed. 2019. China's New Silk Road: An Emerging World Order. Routledge: Abingdon 2019.

103. Mobley, Terry. 2019. The belt and road initiative: Insights from China's backyard. Strategic Studies Quarterly 13 (3): 52-72.

104. Negara, Siwage Dharma and Leo Suryadinata. 2019. China's Maritime Silk Road Initiative and Indonesia. In China's 21st Century Maritime Silk Road Initiative and Southeast Asia: Dilemmas, Doubts, and Determination, ed. Jean-Marc F. Blanchard. Singapore: Palgrave MacMillan, 65-94.

105. People's Republic of China, National Development and Reform Commission, Ministry of Foreign Affairs, and Ministry of Commerce (with State Council authorization), "Visions and Actions on Jointly Building Silk Road Economic Belt and 21 st_Century Maritime Silk Road," March 28, 2015, https://en. ndrc.gov.cn/newsrelease 8232/201503/t20150330 1193900.html

106. Perlez, Jane and Yufan Huang. 2017. Behind China's \$1 Trillion Plan to Shake Up the Economic Order. The New York Times, May 13. https://www.nytimes.com/2017/05/13/business/china-railway-one-beltone-road-1-trillion-plan.html

107. Ploberger, Christian. 2020. Political Economic Perspectives of China's Belt and Road Initiative: Reshaping Regional Integration. London: Routledge.

108. Rana, Pradumna B., and Xianbai Ji. 2020. China's Belt and Road Initiative: Impacts on Asia and Policy Agenda. Singapore: Springer.

109. Ren, Xiaojin and Chen Meiling. 2019. "Belt, Road Markets Drive Strong Growth in Exports, Imports," China Daily, May 10. http://www.chinadaily.com.cn/a/201905/10/WS5cd4d315a3104842260bae58. html

110. Rimmer, Peter J. 2018. China's belt and road initiative: Underlying economic and international relations dimensions. Asian-Pacific Economic Literature 32 (2): 3-26.

111. Robinson, Thomas W., and David L. Shambaugh, eds. 1994. Chinese Foreign Policy: Theory and Practice. Oxford: Clarendon Press.

112. Roland, Nadege, ed. 2019. Security the Belt and Road Initiative: China's Evolving Military Engagement along the Silk Roads," NBR Special Report 80. https:/www.nbr.org/publication/ securing-the-belt-and-road-prospects-for-chinese-military-engagement-along-the-silk-roads

113. Rolland, Nadege. 2019. Reports of Belt and Road's Death are Greatly Exaggerated. Foreign Affairs, January 29. https://www.foreignaffairs.com/articles/china/2019-01-29/reports-belt-and-roads-death-aregreatly-exaggerated

114. Sagi, Judit, and Istvan Engelberth. 2018. The belt and road initiative-a way forward to China's expansion. Contemporary Chinese Political Economy and Strategic Relations 4 (1): 9-37.

115. Sakhuja, Vijay, and Jane Chan, eds. 2016. China's Maritime Silk Road and Asia. New Delhi: VIJ Books.

116. Shan, Wenhua, Kimmo Nuotio, and Kangle Zhang, eds. 2018. Normative Readings of the Belt and Road: Road to New Paradigms. Cham: Springer.

117. Sharma, Anu. 2019. An analysis of 'belt and road' initiative and the Middle East. Asian Journal of Middle Eastern and Islamic Studies 13 (1): 35-49.

118. Sharma, B.K., and Nivedita Das Kundu, eds. 2016. China's One Belt One Road. New Delhi: VIJ Books.

119. Shichor, Yitzhak. 2018. Vision, Revision, and Supervision: The Politics of China's OBOR and AIIB and their Implications for the Middle East. In China's Presence in the Middle East: The Implications of the One Belt, One Road Initiative, eds. Anoushiravan Ehteshami and Niv Horesh. Abingdon: Routledge, 38-53.

120. Simelane, Thokozani, and Lavhelesani Managa, eds. 2018. Belt and Road Initiative: Alternative Development Path for Africa. Pretoria: Africa Institute of South Africa.

121. Sooksripaisarnkit, Poomintr, and Sai Ramani Garimella, eds. 2018. China's One Belt One Road Initiative and Private International Law. Abingdon: Routledge.

122. Stokes, Jacob. 2015. China's road rules. Foreign Affairs, April 19. https://www.foreignaffairs.com/ articles/asia/2015-04-19/chinas-road-rules

123. Styan, David. 2020. China's maritime silk road and small states: Lessons from the case of Djibouti. Journal of Contemporary China 29 (122): 191-206.

124. Summers, Tim. 2016. China's 'new silk roads': Sub-national regions and networks of global political economy. Third World Quarterly 37 (9): 1628-1743.

125. Syed, Jawad and Yung-Hsiang Ying, eds. 2019. China's Belt and Road Initiative in a Global Context, Vol. I: A Business and Management Perspective. Cham: Springer.

126. Tekdal, Veysel. 2018. China's belt and road initiative: At the crossroads of challenges and ambitions. The Pacific Review 31 (3): 373-390. 
127. van der Putten, Frans-Paul. 2019. European seaports and Chinese strategic influence. Cingendael Report, December. https://www.clingendael.org/sites/default/files/2019-12/Report_European_ports_ and Chinese influence_December_2019.pdf

128. Visvizi, Anna, Miltiadis D. Lytras, Wadee Alhalabi, and Xi Zhang, eds. 2019. The new silk road leads through the Arab peninsula: Mastering global business and innovation. Bingley: Emerald Publishing.

129. Wang, Guiguo. 2017. The belt and road initiative in quest for a dispute resolution mechanism. Asia Pacific Law Review 25 (1): 1-16.

130. Wang, Yong. 2016. Offensive for defensive: The belt and road initiative and China's new grand strategy. The Pacific Review 29 (3): 455-463.

131. Williams, Jessica M. 2019. Emerging costs of China's belt and road strategy for Transboundary water in south and Southeast Asia. International Journal of Energy and Water Resources 3: 81-92.

132. Xing, Li, ed. 2019. Mapping China's 'One Belt One Road' Initiative. Cham: Palgrave MacMillan.

133. Xing, Li. 2019. China's Pursuit of the 'One Belt One Road' Initiative: A New World Order with Chinese Characteristics? In Mapping China's 'One Belt One Road' Initiative, ed. Li Xing. Cham: Palgrave MacMillan, 1-27.

134. Xinhua. 2019. 283 Items of Outcomes Achieved at Second Belt and Road Forum, April 27. http://www. xinhuanet.com/english/2019-04/27/c_138015765.htm

135. Yamada, Go and Stefania Palma. 2018. Is China's belt and road working? A Progress Report from Eight Countries. Nikkei Asia, March 28. https://asia.nikkei.com/Spotlight/The-Big-Story/Is-China-sBelt-and-Road-working-A-progress-report-from-eight-countries

136. Yang, Shisheng. 2018. The cultural orientation of 'belt and road' strategy and the construction of its cultural pattern. Canadian Social Science 14 (11): 11-18.

137. Yang, Yue, and Li Fujian, eds. 2019. The Belt and Road Initiative: ASEAN Countries' Perspectives. Singapore: World Scientific.

138. Ye, Min. 2019. Fragmentation and mobilization: Domestic politics of the belt and road in China. Journal of Contemporary China 28 (119): 696-711.

139. Ye, Min. 2020. The Belt and Road and Beyond: State-Mobilized Globalization in China: 1998-2018. Cambridge: Cambridge University Press.

140. Young, Sokphea. 2020. China's belt and road initiative: Patron-client and capture in Cambodia. The Chinese Journal of Comparative Law 8 (2): 414-434.

141. Yu, Hong. 2017. Motivation behind China's 'one belt, one road,' initiatives and establishment of the Asian infrastructure investment bank. Journal of Contemporary China 26 (105): 353-368.

142. Zhang, Jie, ed. 2017. China's Belt and Road Initiatives and its Neighboring Diplomacy, trans. XU Mengqi. Singapore: World Scientific Publishing.

143. Zhang, Wenxian, Ilan Alon, and Christoph Lattemann, eds. 2018. China's Belt and Road Initiative: Changing the Rules of Globalization. Cham: Palgrave Macmillan.

144. Zhao, Quansheng. 1996. Interpreting Chinese foreign policy: The micro-macro linkages approach. Hong Kong: Oxford University Press.

145. Zhao, Suisheng, ed. 2004. Chinese Foreign Policy: Pragmatism and Strategic Behavior. London: Routledge.

146. Zhao, Suisheng, ed. 2016. The Making of China's Foreign Policy in the $21^{\text {st }}$ Century: Historical Sources, Institutions/Players, and Perceptions of Power Relations. London: Routledge.

147. Zhao, Suisheng. 2020. China's belt-road initiative as the signature of president xi Jinping diplomacy: Easier said than done. Journal of Contemporary China 29 (123): 319-335.

148. Zhao, Yun, ed. 2018. International Governance and the Rule of Law in China under the Belt and Road Initiative. New York: Cambridge University Press.

149. Zheng, Chongwei, Jianjun Xu, Chao Zhan, and Qing Wang. 2020. 21st Century Maritime Silk Road: Wave Energy Resource Evaluation. Singapore: Springer Nature.

150. Zhou, Weifeng, and Mario Esteban. 2081. Beyond balancing: China's approach towards the belt and road initiative. Journal of Contemporary China 27 (112): 487-501. 
Jean-Marc F. Blanchard (白永辉), Ph.D. is Distinguished Professor, School of Advanced International and Area Studies, East China Normal University (China) and Founding Executive Director of the Mr. \& Mrs. S.H. Wong Center for the Study of Multinational Corporations (USA). He is a co-author of Economic Statecraft and Foreign Policy, the editor or co-editor of and a contributor to 18 edited volumes and special journal issues, and the author of nearly seventy articles, book chapters, and other scholarly publications. An expert on the political economy of national security and China's foreign economic relations, he organized, edited, and contributed to China's Maritime Silk Road Initiative and South Asia (2018) and China's Maritime Silk Road and Southeast Asia (2019) and has orchestrated and contributed to special journal issues on China's MSRI and South Asia and China's MSRI and Southeast Asia. He also has a forthcoming book entitled China's Maritime Silk Road, Africa, and the Middle East (2021). He received his Ph.D. and M.A. from the University of Pennsylvania. Prior to his career in academia, he worked for the U.S. Federal Savings \& Loan Insurance Corporation and Federal Deposit Insurance Corporation and the investment banking firm Kelling, Northcross, \& Nobriga. 